\title{
Bone-marrow transplantation for severe aplastic anaemia using histocompatible unrelated volunteer donors
}

\author{
E C GORDON-SMITH, S M FAIRHEAD, P M CHIPPING, J HOWS, D C O JAMES, A DODI, \\ J R BATCHELOR
}

\begin{abstract}
Two patients with severe aplastic anaemia received bone-marrow transplants from unrelated donors selected for HLA compatibility. Graft-versus-host disease occurred in both patients but responded to treatment. Both patients had stormy courses after grafting, but subsequently their conditions improved, and one was not receiving any treatment at follow-up after day 330 while the other had mild chronic graft-versus-host disease at day 150.

These results show that unrelated, histocompatible volunteers may successfully donate marrow for the treatment of severe aplastic anaemia, though many problems remain to be solved.
\end{abstract}

\section{Introduction}

Bone-marrow transplantation from histocompatible sibling or family donors is the treatment of choice for severe aplastic anaemia. ${ }^{12}$ The size of families in Europe and North America restricts this approach to about one in three affected patients. Alternative forms of treatment include immunosuppression with antilymphocyte globulin ${ }^{3}$ or high-dose methylprednisone ${ }^{4}$ followed by anabolic steroids. Immunosuppression given in this

\footnotetext{
Department of Haematology, Royal Postgraduate Medical School, London W12 0HS

E C GORDON-SMITH, MA, FRCP, senior lecturer in haematology S M FAIRHEAD, MRCPATH, MRCP, senior registrar in haematology P M CHIPPING, MRCPATH, MRCP, senior registrar in haematology J HOWS, MRCPATH, MRCP, research fellow, Leukaemia Research Fund

Anthony Nolan Appeal Fund, St Mary Abbott's Hospital, London W8 5LQ

D C O JAMES, MSC, FRCPATH, director, Anthony Nolan Appeal Fund

Department of Immunology, Royal Postgraduate Medical School, London W12 0HS

A DODI, MIBIOL, senior technician

J R BATCHELOR, MD, professor of immunology
}

way has about a $50 \%$ failure rate, which may be higher in patients who have serious infectious complications. Bone-marrow transplantation from histocompatible unrelated donors or from mismatched related donors offers an alternative form of treatment. We report here the clinical courses of two patients with severe aplastic anaemia who received transplants from unrelated donors selected for HLA compatibility.

\section{Case reports}

CASE 1

A 19-year-old girl student presented in March 1981 with a short history of easy bruising after an episode of non-A non-B hepatitis one month before. Blood count, bone-marrow aspirate, and a trephine biopsy specimen showed that she had severe aplastic anaemia (haemoglobin concentration $6.4 \mathrm{~g} / \mathrm{dl}$, reticulocytes $<0.1 \%$; white cell count $0.2 \times 10^{\%} / 1$, no neutrophils; platelets $10 \times 10^{9} / 1$; bone marrow $>80 \%$ of cells non-myeloid). She was an only child and her parents were not histocompatible. She was transferred to Hammersmith Hospital for treatment with antilymphocyte globulin (Merieux) and anabolic steroids. At the same time a search for an unrelated donor was instituted through the computer records of volunteers kept by the Anthony Nolan Fund. The table shows details of the tissue typing results.

During the next three months her condition deteriorated. She became refractory to platelet transfusions and had several episodes of septicaemia, with Staphylococcus epidermidis grown from the blood on several occasions. Klebsiella aeruginosa was repeatedly cultured from her throat, faeces, and urine. She was treated with appropriate antibiotics including aminoglycosides and suffered some ototoxicity. Before grafting she received 33 units of packed cells, platelets from $\mathbf{4 7 0}$ random donors, and 15 donations of leucocytes from patients with chronic granulocytic leukaemia. On 16 July (day 0 ) she received $3.27 \times 10^{8}$ nucleated cells $/ \mathrm{kg}$ body weight, aspirated from the bone marrow of donor 3, after immunosuppression with cyclophosphamide $50 \mathrm{mg} / \mathrm{kg} /$ day for four days. Post-transplant immunosuppression was continued with oral cyclosporin A, $12.5 \mathrm{mg} / \mathrm{kg}$ twice daily for four days from day -1 , then $6.25 \mathrm{mg} / \mathrm{kg}$ day for a further six months. Evidence of haemopoietic reconstitution occurred on day 8 with the appearance of granulocytes in the peripheral blood. She required red-cell and platelet support until days 145 and 128 respectively. Major complications after grafting included pneumonitis and encephalitis caused by 
herpes zoster, which responded to acyclovir and intermittent positivepressure ventilation, and severe graft-versus-host disease (grade III) of the skin and gastrointestinal tract at day 21, which responded to high-dose methylprednisolone.

She was finally discharged on day 157. Proof of allogeneic engraftment was obtained by chromosome analysis, which showed all peripheral blood mitoses to be $46 \mathrm{XY}$ at day 150 . Follow-up, after day 330, showed her to be well apart from moderate hearing loss; she was not taking any treatment and had resumed her studies. Haemoglobin concentration was $9.0 \mathrm{~g} / \mathrm{dl}$, reticulocytes $4.5 \%$; white cell count $10 \times 10^{\%} / 1$, neutrophils $3.5 \times 10^{9} / 1$; and platelets $174 \times 10^{9} / 1$.

\section{CASE 2}

A 22-year-old male student presented in October 1981 tired, short of breath, and with bleeding gums. His blood count showed haemoglobin concentration $8 \cdot 8 \mathrm{~g} / \mathrm{dl}$ after four units of blood; reticulocytes were $>0 \cdot 1 \%$, white cell count $2 \cdot 1 \times 10^{9} / 1$ with $30 \%$ neutrophils, and platelets $15 \times 10^{9} / 1$. A bone-marrow aspirate and trephine biopsy specimen showed severe aplastic anaemia. His parents and sister were not histocompatible. A search for a suitable unrelated donor was started through the Anthony Nolan Fund (table). Until January 1982

Details of histocompatibility testing for unrelated bone-marrow donor

\begin{tabular}{|c|c|c|c|c|c|c|c|}
\hline & \multirow{2}{*}{ Sex } & \multicolumn{3}{|c|}{ HLA typing } & \multirow[b]{2}{*}{ DR } & \multirow{2}{*}{$\begin{array}{c}\text { Host-versus- } \\
\text { graft } \\
\text { activity }(\%)\end{array}$} & \multirow{2}{*}{$\begin{array}{c}\text { Graft-versus- } \\
\text { host } \\
\text { activity }(\%)\end{array}$} \\
\hline & & A & B & $\mathrm{CW}$ & & & \\
\hline 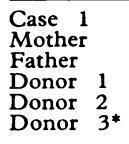 & $\begin{array}{l}F \\
F \\
M \\
F \\
M \\
M\end{array}$ & $\begin{array}{l}2,23 \\
2,23 \\
2,1 \\
2,23 \\
2,24 \\
2,24\end{array}$ & $\begin{array}{c}40,44 \\
7,44 \\
40,8 \\
40,44 \\
40,44 \\
40,44\end{array}$ & $\begin{array}{l}3,4 \\
4 \\
3 \\
3,4 \\
3 \\
3,4\end{array}$ & $\begin{array}{l}\text { ND } \\
2,7 \\
4,3 \\
4 \\
4,7 \\
7\end{array}$ & $\begin{array}{l}\text { ND } \\
\text { ND } \\
194 \\
123 \\
11 \cdot 3\end{array}$ & $\begin{array}{l}\text { ND } \\
\text { ND } \\
9 \cdot 8 \\
0 \cdot 45 \\
0 \cdot 36\end{array}$ \\
\hline $\begin{array}{ll}\text { Case 2 } & \\
\text { Donor } & 4 \\
\text { Donor } & 5 \\
\text { Donor } & 6 \\
\text { Donor } & 7 \\
\text { Donor } & 8 \\
\text { Donor } & 9^{*} \\
\text { Donor } 10\end{array}$ & $\begin{array}{l}M \\
M \\
F \\
F \\
F \\
F \\
F \\
M\end{array}$ & $\begin{array}{l}2,29 \\
2,29 \\
2,29 \\
2,29 \\
2,29 \\
2,29 \\
2,29 \\
2,29\end{array}$ & $\begin{array}{l}13,44 \\
44 \\
13,44 \\
13,44 \\
13,44 \\
13,44 \\
13,44 \\
13,44\end{array}$ & $\begin{array}{l}6 \\
6 \\
6\end{array}$ & $\begin{array}{l}2,7 \\
7 \\
7 \\
7 \\
4,7 \\
\text { ND } \\
7 \\
7\end{array}$ & $\begin{array}{l}\text { ND } \\
201 \\
287 \\
128 \\
\mathrm{ND} \\
24 \\
86\end{array}$ & $\begin{array}{l}\text { ND } \\
11 \cdot 8 \\
45 \\
45 \\
\text { ND } \\
12 \\
69\end{array}$ \\
\hline
\end{tabular}

* Donor finally chosen.

ND = Not done or technical fatlure. Footnote: Despite several attempts we failed to prepare technically satisfactory
suspensions of B lymphocytes for DR typing in case 1 . Compatibility was therefore judged from the mixed lymphocyte culture data, donor 3 being selected. On the basis of the parental DR types, four DR phenotypes were possible for the patient, none of which was identical with the DR phenotype of donor 3. It is interesting that, despite (presumptive) DR non-identity, mutually negative one-way mixed lymphocyte cultures were observed between the cells in case 1 and donor 3 . There was also a single HLA-A locus antigenic difference between them. Similarly case 2 had HLADR2,7 but donor 9 had only DR7; but mutually negative mixed lymphocyte culture responses were observed.

he was managed with blood-product support (about 50 units of packed red cells and 96 units of platelets from random donors). Major problems were gastrointestinal haemorrhage and fever with recurrent sore throat, treated with intravenous antibiotics.

In January he was transferred to Hammersmith Hospital for bonemarrow transplantation from a donor (donor 9). Immunosuppression was given with antilymphocyte globulin (Merieux) on days $-7,-5$, and -3 ; procarbazine $12.5 \mathrm{mg} / \mathrm{kg} /$ day on days $-6,-4$, and -2 ; and cyclophosphamide $50 \mathrm{mg} / \mathrm{kg} /$ day on days -5 to -2 inclusive. He was also given intravenous cyclosporin A $5 \mathrm{mg} / \mathrm{kg}$ twice daily on days - 4 to -1 inclusive, when he was switched to oral cyclosporin A $6.25 \mathrm{mg} / \mathrm{kg}$ twice daily; this was discontinued at day 10 because of deteriorating renal function. On 24 February (day 0 ) he received $2.6 \times 10^{8}$ nucleated cells $/ \mathrm{kg}$ body weight aspirated from the marrow of donor 9. Neutrophils appeared in the peripheral blood at day 8 , but he required red-cell and platelet support until day 42. Major complications after grafting included hepatorenal failure, which required haemodialysis for 21 days, and acute skin graft-versus-host disease (grade III at day 6), which responded to high-dose methylprednisolone.

He was discharged at day 65 with normal blood counts. He was not receiving cyclosporin $A$ because reintroduction of the drug had produced an allergic reaction. On day 75 he showed evidence of chronic rash, which generalised, and he developed a sicca syndrome typical of chronic graft-versus-host disease. This responded (day $150+$ ) to prednisone and azathioprine. Allogeneic engraftment was confirmed by the finding of $46 \mathrm{XX}$ chromosomes in all mitoses from peripheral blood and marrow on day 100 . Haemoglobin concentration was $12.0 \mathrm{~g} / \mathrm{dl}$, reticulocytes $1.5 \%$; white cell count $3.8 \times 10^{9} / 1$, neutrophils $2.3 \times 10^{9} / 1$; and platelets $130 \times 10^{9} / 1$.

\section{Previous experience with unrelated donors}

In 1975 we attempted to graft two patients with marrow from unrelated donors who were HLA-A and B identical and negative on testing for mixed lymphocyte reaction. One patient had Fanconi's anaemia, while the other had end-stage acute lymphocytic leukaemia. The patients were treated with methotrexate to prevent graft-versushost disease, and the one with acute lymphocytic leukaemia received 1000 rads total body irradiation. Both patients died without evidence of haemopoietic reconstitution. The patient with Fanconi's anaemia had a severe exfoliative skin lesion with candida present.

\section{Selection of donors}

Potential donors were identified from the Anthony Nolan Fund panel. A computer search through 45000 donors' records selected volunteers who were $\mathrm{ABO}$ and HLA-A and $\mathrm{B}$ identical (category 1) or $\mathrm{ABO}$ incompatible and HLA-A and B identical (category 2). These volunteers had signified their willingness to give bone marrow when they joined this panel. Blood was sent to Hammersmith Hospital for HLA-DR typing. ${ }^{5}$ When HLA-DR compatible donors had been identified they were asked to attend Hammersmith Hospital to give blood for mixed lymphocyte reaction testing. One-way mixed lymphocyte cultures were performed using cells from those donors who appeared to match the recipient most closely and the recipient's lymphocytes. A conventional semi-micro mixed lymphocyte culture method was employed, based on a method of Sengar and Terasaki. ${ }^{6}$ Host-versus-graft and graft-versus-host activities were calculated as follows:

$$
\begin{aligned}
& \text { Host-versus-graft }=\frac{R+S_{1}-R+R_{1}}{R+X_{1}-R+R_{1}} \times 100 \\
& \text { Graft-versus-host }=\frac{S+R_{1}-S+S_{1}}{S+X_{1}-S+S_{1}} \times 100
\end{aligned}
$$

where $\mathrm{R}=$ patient, $\mathrm{S}=$ potential donor, $\mathrm{X}=$ third party control, and subscript ${ }_{1}$ indicates irradiated cells. Figures of $>35 \%$ were considered to be positive.

Before bone-marrow transplantation the sera of the recipients were tested for lymphocytotoxic antibodies reactive with the chosen donor's cells and were found to be negative. Data on histocompatibility are shown in the table.

On their first visit the donors were seen by a member of the transplant team and asked if they still felt that they would like to give marrow and the nature of the procedure was explained to them. They were asked if they had any history of illness and to provide the name and address of their general practitioner. None of the potential donors screened in this way expressed any doubts about their willingness to proceed as a donor. Once it became established that full histocompatibility was present the compatible donor was asked to attend for further explanation of the procedure, for medical examination by a physician, and for blood count, chest radiography, and electrocardiography. The patient's general practitioner was contacted for information about his history and exposure to drugs. One of the potential donors had a history of depression for which prothiaden had been given but discontinued three months previously. The general practitioner expressed some concern about using this particular donor. After discussion with other colleagues and the general practitioner we felt that to reject a donor on the grounds of previous depression would be more harmful than proceeding and risking relapse of depression should the graft fail. Potential donors were given a further chance to withdraw at this time, when it was explained that other donors were available should they wish to do so. Discussion with family members was arranged as required. Finally, a written account was provided of the procedures the donor would undergo and the donor signed a standard consent form.

The procedures entail donating $500 \mathrm{ml}$ blood 10 days before marrow harvest, which is returned at the time of harvest; undergoing a general anaesthetic given by a consultant anaesthetist, which lasts $1 \frac{1}{2}-2$ hours donating about 11 of marrow mixed with blood; and staying in hospital for about 48 hours. The white cell count and platelet counts are unaffected by the marrow harvest, and ferrous sulphate is given for one month or more if required to correct any iron loss. 


\section{Discussion}

Successful bone-marrow transplantation from an unrelated donor has been reported for treatment of acute myeloid leukaemia in remission. ${ }^{7}$ It has not been reported before in the treatment of severe aplastic anaemia with evidence of sustained engraftment, though unsuccessful attempts have been made. ${ }^{8} 9$ Both the patients reported on here received many blood transfusions. Multiple blood transfusions are associated with an increased risk of graft rejection in aplastic anaemia, ${ }^{10}$ though possibly the use of cyclosporin A permitted engraftment in our patients despite this problem. ${ }^{11}$ Graft-versus-host disease occurred in both patients but in each case the acute episodes responded to treatment. The man had chronic graft-versus-host disease of the skin, which seemed to respond to prednisone and azathioprine. Both patients had stormy courses after grafting. Some of the infectious complications in the woman may have been related to the delay in bone-marrow transplantation since she had proved septicaemia before starting. Herpes zoster infections are common after grafting. ${ }^{12}$ The hepatic and renal failure in the man was probably related to drug treatment, including intravenous cyclosporin $\mathrm{A}$ and antibiotics. ${ }^{13}$ These patients show, however, that unrelated volunteers may donate marrow successfully for the treatment of severe aplastic anaemia. There are many logistical problems in this procedure that cause delay in identifying suitable donors, and the ethical questions raised in giving an anaesthetic to a healthy volunteer need wider discussion. The use of mismatched family donors has not yet been explored in aplastic anaemia, mainly because the increased problems encountered using these donors in leukaemic patients ${ }^{14}$ may prove difficult to overcome in patients with aplastic anaemia, who are generally more ill. Despite the problems encountered in the management of these two patients, bone-marrow transplantation from unrelated, histocompatible donors does offer a chance of cure in severe aplastic anaemia.

\section{References}

${ }^{1}$ Camitta BM, Thomas ED, Nathan DG, et al. Severe aplastic anaemia: a prospective study of the effect of early marrow transplantation on acute mortality. Blood 1976;48:64-70.

2 UCLA Bone Marrow Transplant Team. Bone marrow transplantation in severe aplastic anaemia. Lancet 1976;ii:921-3.

${ }^{3}$ Speck B, Gratwohl A, Nissen C, et al. Treatment of severe aplastic anaemia with antilymphocyte globulin or bone marrow transplantation. $\mathrm{Br} \mathrm{Med} \mathcal{F}$ $1981 ; 282: 860-3$

${ }^{4}$ Bacigalupo A, Podesta M, Van Lint MT, et al. Severe aplastic anaemia: correlation of in vitro tests with clinical response to immunosuppression in 20 patients. Br $\mathcal{F}$ Haematol $1981 ; 47: 423-42$.

${ }^{5}$ Wooley P, Griffin J, Panayi GS, Batchelor JR, Welsh KI, Gibson TJ. HLA-DR antigens and toxic reaction to sodium aurothiomalate and D-penicillamine in patients with rheumatoid arthritis. $N$ Engl $\mathcal{F}$ Med 1980;303:300-2.

6 Sengar DPS, Terasaki PI. A semimicro mixed leukocyte culture test. Transplantation 1971;11:260-7.

${ }^{7}$ Hansen JA, Clift RA, Thomas ED, Buckner CD, Storb R, Giblett ER. Transplantation of marrow from an unrelated donor to a patient with acute leukaemia. $N$ Engl f Med 1980;303:565-7.

${ }^{8}$ Speck B, Zwaan FE, van Rood JJ, Eernisse JG. Allogeneic bone marrow transplantation in a patient with aplastic anaemia using a phenotypically HL-A-identical unrelated donor. Transplantation 1973;16:24-8.

${ }^{9}$ Lohrmann HP, Dietrich M, Goldmann SF, et al. Bone marrow transplantation for aplastic anaemia from a HL-A and MLC-identical unrelated donor. Blut $1975 ; 31: 347-54$

10 Storb R, Prentice RL, Thomas ED. Marrow transplantation for aplastic anaemia. Factors associated with rejection. $N$ Engl f Med 1977;296:61-6.

${ }^{11}$ Hows JM, Palmer S, Gordon-Smith EC. Use of cyclosporin A in allogeneic bone marrow transplantation for severe aplastic anaemia. Transplantation 1982;33:382-6.

12 Atkinson K, Meyers JD, Storb R, Prentice RL, Thomas ED. Varicellazoster virus infection after marrow transplantation for aplastic anaemia or leukaemia. Transplantation 1980;29:47-50.

${ }^{13}$ Powles RL, Morgenstern GR. Allogeneic bone marrow transplantation using mismatched family donors. In: White D, Powles $\mathrm{R}$, McMasters $\mathrm{P}$, Davis A. Proceedings of the international symposium on cyclosporin A. Amsterdam: Elsevier (in press).

${ }^{14}$ Hows JM, Palmer S, Want S, Dearden D, Gordon-Smith EC. Serum levels of cyclosporin $\mathrm{A}$ and nephrotoxicity in bone marrow transplant patients. Lancet 1981 ;ii:144-5.

(Accepted 6 August 1982)

\title{
Pyoderma gangrenosum associated with primary thrombocythaemia
}

\author{
PAUL SHEPHERD, KEITH LIDDELL
}

\begin{abstract}
Pyoderma gangrenosum is most commonly associated with inflammatory bowel disease and rheumatoid arthritis, but it has been associated with various haematological malignancies. A 54-year-old man with no history of bowel disease or arthritis presented with a leg ulcer, which healed after treatment. Results of bone marrow aspiration were compatible with primary thrombocythaemia. Seven weeks later there was pronounced recurrence of the ulceration and pyoderma gangrenosum was diagnosed.
\end{abstract}

District General Hospital, Eastbourne, East Sussex BN21 2UD PAUL SHEPHERD, MB, BS, house physician (now: general practitioner vocational trainee)

KEITH LIDDELL, MD, MRCP, consultant dermatologist
The appearance of pyoderma gangrenosum associated with blood disorders may differ from that associated with bowel and joint disease.

\section{Introduction}

Pyoderma gangrenosum has been rarely associated with various haematological malignancies. We report an association with primary thrombocythaemia.

\section{Case report}

A 54-year-old Caucasian man presented with a four-week history of increasing ulceration on the outer aspect of the left lower leg. There was no history of bowel disease, varicose veins, or arthritis, and peripheral pulses in the legs were strong. Results of investigations at this time were: haemoglobin $15 \cdot 1 \mathrm{~g} / \mathrm{dl}$, red cell count $6.68 \times 10^{12} / \mathrm{l}$, packed cell volume $0 \cdot 464$, white cell count $16.4 \times 10^{9} / 1$, and platelets $1210 \times 10^{9} / 1$; leucocyte alkaline phosphatase activity was normal. The 